\title{
SOCIO-PSYCHOLOGICAL ANALYSIS OF CONTENT AND STRUCTURE OF COMMUNICATIVE COMPETENCI ES OF BORDERGUARD CADETS
}

\section{Halyna Topolnytska}

\section{INTRODUCTION}

The fundamental theoretical basis for interdisciplinary research in the problems of personality development and formation, to which the culture of interpersonal relations belongs, is the provision on the human social essence. The personality crystallizes in own psychological structure of social relations, and at the same time personality. becomes their object and subject.

The category of «relationship» becomes the «common territory, a subject that belongs at the same time to both psychology and ethics.» S. Rubinstein noted that relationships are «the core of real-life psychology», «the realm of the» intersection «of psychology with ethics» ${ }^{1}$ (Rubinshtein, 1989). Using the category of relations as the basic one, one should pay attention to the concept of relations V. Myasishchev, who characterized the study of relations as «... an important approach in psychology, which combines the objective with the subjective, external with internal» ${ }^{2}$ (Miasishchev, 1995a). From this point of view, the relationship as a subject-subject relationship is not only a socio-psychological but also a cultural category, that is, in the phenomenon of relations, the unity of psychological and social is realized.

The concept of relations of V. Myasishchev foresees at least four points when analyzing the phenomenon of "relationship" itself. Firstly, this is the need for another, in which V. Myasishchev understood «... the cognitive tendency to master another person $»^{3}$ (Miasishchev, 1995b). This is a distinction between two basic needs: the need for communication and the need for co-operation.

Secondly, it is an interest in the other as an «active emotional-cognitive attitude to another person.»

The scientist distinguished two types of interest: interest in the personal sphere, that is, experiences, feelings and unique originality and interest in the

${ }^{1}$ Rubinshtein S.L. (1989). Osnovy obshchei psikhologii. V 2 t. T. 1 [Fundamentals of General Psychology. In 2 vols. Vol. 1]. Moscow: APN USSR. P. 328. [in Russian].

${ }^{2}$ Miasishchev V.N. (1995). Psikhologiia otnoshenii [Psychology of relations]. Moscow. 229 p. [in Russian].

${ }^{3}$ Miasishchev V.N. (1995). Psikhologiia otnoshenii [Psychology of relations]. Moscow. 229 p. [in Russian]. 
intellectual sphere of personality. Thirdly, it is an emotional attitude to another. According to V. Myasishchev, it «... manifests in affection, love, sympathy and their opposites - hostility, obscurity, antipathy» ${ }^{4}$ (Miasishchev, 1995c). And finally, fourthly, is the evaluation relationship, which the scientist defined as «The process of comparison of actions and deeds with samples» ${ }^{5}$ (Miasishchev, 1995d).

Interpersonal relationships, both objectively experienced and to a different degree by conscious relationships between people, are closely linked to different types of social interactions. «Interpersonal relationships within different forms of social relations are the direct realization of impersonal relationships in the activities of particular individuals, in the acts of their communication and interaction» ${ }^{6}$ (Naprasna, 2004). Thus, the culture of interpersonal relationships is thus a reflection of the socio-cultural situation in the country, region, State Border Guard Service of Ukraine, etc. and confront the socio-cultural situation as a single with the general, and the problem research of the culture of cadets interpersonal relationships, and from a psychological point of view seems quite reasonable.

\section{Psychological analysis of communicative competencies content of border guard cadets}

Considering the culture of interpersonal relationships as a result of reflecting the impact of the macro environment on each subject of interaction, it is necessary to distinguish several sociocultural characteristics of communicative competence that change as the environment changes. These characteristics, which are described in cross-cultural psychology as cultural syndromes, are essentially tools for the psychological dimension of culture. Among the main cultural features are «individualism collectivism», «simplicity - complexity», «openness - closedness» of the collective culture ${ }^{7}$ (Buzin, 1992).

Without doing a detailed analysis of each of the syndromes of «individualism - collectivism», «simplicity - complexity», «openness -

\footnotetext{
${ }^{4}$ Miasishchev V.N. (1995). Psikhologiia otnoshenii [Psychology of relations]. Moscow. 229 p. [in Russian].

${ }_{5}^{5}$ Miasishchev V.N. (1995). Psikhologiia otnoshenii [Psychology of relations]. Moscow. 229 p. [in Russian].

6 Naprasna O.B. (2004). Indyvidualno-psykholohichni osoblyvosti kohnityvno-stylovykh kharakterystyk navchalnoi diialnosti studentiv: Dys... kand. psykhol. nauk [Individual-psychological features of cognitive-style characteristics of students' educational activity: Dis ... Cand. psych. sciences]. Kyiv: The Taras Shevchenko National University of Kyiv. P. 188. [in Ukrainian]

${ }^{7}$ Buzin E. V. (1992). Mezhlichnostnoe ponimanie kak faktor effektivnosti uchebnoprofessionalnoi deiatelnosti gruppy kursantov Avtoref dis kand psikhol nauk [Interpersonal understanding as a factor in the effectiveness of educational and professional activities of a group of cadets: Author's abstract. diss. psych. sciences]. Kyiv. P. 22 [in Russian].
} 
closedness» of culture, let us note only that the communicative competencies of cadets-border guards will be considered within the basic dimension of cultural variability, namely in dimension «Collectivism-individualism». The expediency of such consideration of interpersonal relations is determined by at least two circumstances: the first is based on the results of those ethnopsychological researches that classify our Slavic culture to collectivist-type cultures, and, secondly, the significance given in the domestic sociopsychological phenomena such as «social-psychological unity», «cohesion», «disunity», «compatibility», which are the essence of the psychological theory of the collective ${ }^{8}$ (Topolnytska, 2006).

Although the essence of the differences in the collectivist and individualistic nature of communicative competences has been studied for over a hundred years, no systematic experimental studies have been conducted in this direction. However, analyzing interpersonal relationships and knowing the results of their psychological knowledge abroad, as well as summarizing the idea of communicative competencies of domestic researchers, we try to uncover the features of interpersonal relationships that have a collectivist and individualistic orientation (Table 1.1).

Based on the analysis of scientific sources, the main sociocultural categories, which are, on the one hand, forms of culture, and on the other forms of mental reflection of the subject-cultural world, are knowledge, norm, social model and value. The complexity of these categories requires a separate psychological analysis. But, in one way or another, these categories have basic cultural functions, namely:

streamlining the common life of many people by structuring their social experience;

providing meaningful orientation to any social processes (formation of meaningful constructs of social actions);

ensuring the continuity of generations through their socialization through providing individuals with value-normative coordinates of behavior and norms-prohibitions, frameworks, ideals.

${ }^{8}$ Topolnytska H. Yu. (2006). Zmina sotsialnykh ustanovok i vplyv kolektyvnopsykholohichnykh umov na formuvannia kultury mizhosobystisnykh vidnosyn v kursantskykh kolektyvakh [Changing social attitudes and the influence of collective-psychological conditions on the formation of a culture of interpersonal relations in cadets] // Zbirnyk naukovykh prats. Natsionalnoi akademii DPSU [Published by the National Academy of the SBGS of Ukraine]. P. 134. [in Ukrainian]. 
Table 1.1

\section{Comparison collectivist and individualistic orientationin interpersonal relationships}

\begin{tabular}{|c|c|c|}
\hline $\begin{array}{l}\text { Characteristic of } \\
\text { interpersonal relationships }\end{array}$ & $\begin{array}{l}\text { Collectivist } \\
\text { orientation of } \\
\text { interpersonal relations }\end{array}$ & $\begin{array}{l}\text { Individualistic } \\
\text { orientation of interpersonal } \\
\text { relations }\end{array}$ \\
\hline $\begin{array}{l}\text { The basis is the various } \\
\text { emotional states of interacting } \\
\text { people and their psychological } \\
\text { characteristics }\end{array}$ & $\begin{array}{l}\text { The advantage of } \\
\text { conjunctive affective } \\
\text { experiences }\end{array}$ & $\begin{array}{l}\text { Various emotional states of } \\
\text { interacting people and their } \\
\text { psychological peculiarities }\end{array}$ \\
\hline $\begin{array}{l}\text { Elements } \\
\text { - cognitive component; } \\
\text { - affective component; } \\
\text { behavioral component. }\end{array}$ & $\begin{array}{l}\text { The advantage of } \\
\text { positive behavioral } \\
\text { reactions }\end{array}$ & $\begin{array}{l}\text { The advantage of indifferent } \\
\text { and disjunctive affective } \\
\text { experiences; - the } \\
\text { advantage of indifference, } \\
\text { negative behavioral } \\
\text { reactions }\end{array}$ \\
\hline $\begin{array}{l}\text { Dynamics: } \\
\text { - dating; } \\
\text { - friendly relations; } \\
\text { - social relations; } \\
\text { - hearty relations } \\
\end{array}$ & $\begin{array}{l}\text { Dynamic features of } \\
\text { development do not } \\
\text { differ in a degree of } \\
\text { expressiveness }\end{array}$ & $\begin{array}{l}\text { Concentration on a large } \\
\text { number of dating and } \\
\text { friendships based on the } \\
\text { balance of mutual services }\end{array}$ \\
\hline $\begin{array}{l}\text { The main mechanism of } \\
\text { Development: } \\
\text {-empathy: } \\
\text { cognitive empathy; } \\
\text { emotional empathy; } \\
\text { - effective empathy }\end{array}$ & $\begin{array}{l}\text { Expressiveness of } \\
\text { emotional and acting } \\
\text { empathy in relationships }\end{array}$ & $\begin{array}{l}\text { The advantage of cognitive } \\
\text { empathy; Emotional and } \\
\text { acting are much less } \\
\text { common }\end{array}$ \\
\hline $\begin{array}{l}\text { Levels: } \\
\text { 1) business } \\
\text { 2) game } \\
\text { 3) manipulative } \\
\text { 4) spiritual } \\
\text { 5) primitive } \\
\text { 6) conventional }\end{array}$ & $\begin{array}{l}\text { Relationships take } \\
\text { priority at the spiritual } \\
\text { level, which determines } \\
\text { the degree of } \\
\text { functionality of other } \\
\text { levels }\end{array}$ & $\begin{array}{l}\text { The advantage of business, } \\
\text { manipulative and } \\
\text { conventional relations }\end{array}$ \\
\hline $\begin{array}{l}\text { Forms of interaction: } \\
\text { Collaboration - cooperation; } \\
\text { Adjustment - coordination } \\
\text { conformality; } \\
\text { Competition - rivalry; } \\
\text { Subcontracting - } \\
\text { subordination; } \\
\text { Confrontation - conflict. }\end{array}$ & $\begin{array}{l}\text { Interaction is based on } \\
\text { co-operation, } \\
\text { coordination and } \\
\text { subordination of } \\
\text { conformality }\end{array}$ & $\begin{array}{l}\text { Interaction based on } \\
\text { competition, counteraction, } \\
\text { conventionality }\end{array}$ \\
\hline
\end{tabular}

One of the decisive factors that influences the culture of interpersonal relationships, in addition to knowledge and norms, is the social model.

The social model - is a living example that embodies certain values, norms and knowledge in relationships. The regulation of public life itself is based not so much on verbal-pronounced demands, but on specific examples of the implementation of these cultural precepts. The ability to imitate is 
inherent in each person, it has its own mechanism of implementation (reference groups, leadership). The same psychological mechanism serves the process of generation and functioning of social models ${ }^{9}$ (Yahupov, 2000].

Such categories as "norm", "social model" and "values" are categories of both intrapersonal and interpersonal interaction that have a socio-cultural character (Table 1.2).

Table 1.2

\section{Forms of culture and forms of subject-cultural world mental reflection}

\begin{tabular}{|c|c|}
\hline Forms of culture & $\begin{array}{c}\text { Forms of mental reflection } \\
\text { subject-cultural world }\end{array}$ \\
\hline Knowledge & Cognitive processes \\
\hline Norm & Attitude to the norms and their implementation \\
\hline Social sample & $\begin{array}{c}\text { Identification, imitation, emotional-volitional, evaluation } \\
\text { comparison with the sample }\end{array}$ \\
\hline Value & Meaning and sense \\
\hline
\end{tabular}

A cultural norm is a system of behavioral expectations, cultural perceptions of how people envision or attempt to act. In social terms, the norm puts certain demands on the individual, shapes the expected behavior, understandable to other people.

Cultural norms include:

a) a collective assessment of what the behavior of a representative of a particular culture should be;

b) collective interpretation of what this or that behavior means;

c) personal reactions to behavior, including attempts to impose sanctions on "undesirable" behaviors.

A set of norms constitutes a normative culture that is carefully designed and established in the form of customs, moral rules, institutional regulations, and is a system of standardized, expected means of feeling and action ${ }^{10}$ (Zazhyrko, 1998).

${ }^{9}$ Yahupov V.V. (2000). Upravlinski funktsii ofitsera ta yikh pedahohichnyi zmist [The managerial functions of the officer and their pedagogical content] // Visnyk AU pry Prezydenti Ukrainy [Bulletin of the AU under the President of Ukraine]. Vyd-vo UADU. Vol. 2. P. 307. [in Ukrainian].

${ }_{10}$ Zazhyrko M.P. (1998). Hlybynnopsykholohichni peredumovy aktyvizatsii protsesu spilkuvannia (akmeolohichnyi pidkhid): Dys... kand. psykhol. Nauk [Deep-psychological preconditions for activating the communication process (acmeological approach): Dis ... Cand. Psych. Sciences]. Cherkasy: Cherkasy State University named after B. Khmelnytskyi. P. 47. [in Ukrainian]. 
The culture of communicative competences of cadets is essentially institutionalized because it is defined and enshrined in the form of social norms, rules, that is, acts as a system that satisfies socially approved goals ${ }^{11}$ (Yahupov, 2004). The normative relations of servicemen are defined by the Military Regulations of the Ukrainian Armed Forces, other governing documents and establish a clear framework of their behavior, set the motives and evaluation criteria for certain actions. A notable feature of normative relationships is that, first, they have detailed regulation that relies on legal acts and, secondly, are characterized by «impersonality» because they target all servicemen ${ }^{12}$ (Safin, 1997).

One of the decisive factors influencing the culture of interpersonal relations, in addition to knowledge and norms, is the social model.

The social model - is a living example that embodies certain values, norms and knowledge in relationships ${ }^{13}$ (Leontev, 1971). The regulation of public life itself is based not so much on verbal and spoken demands, but on specific examples of the implementation of these cultural precepts. The ability to imitate is inherent in each person, it has its own mechanism of implementation (reference groups, leadership). The same psychological mechanism serves the process of generation and functioning of social models. One of these examples of interpersonal relationships for cadets is often their own co-workers or direct or direct commanders (bosses). It is their behavior, especially with regard to human relationships, that becomes the object of careful attention and evaluation of successors.

Knowledge, norms and social models, which are in the mind of the cadet in themselves, are only a set of rules where there is no place for the subjective and personal. Social models as knowledge are differ from norms as values. An exclusively value-based, research-based culture is a kind of social mechanism that identifies, coordinates, addresses, reproduces, preserves, protects, develops and transmits values in society ${ }^{14}$ (Bodalev, 1993). In the psychological tradition, values as such are viewed because of the problem of complementarity of meanings and senses. At the same time values are called «relatively stable, socially conditioned, selective attitude of

11 Yahupov V.V. (2004). Viiskova psykholohiia: Pidruchnyk [Military Psychology: Textbook]. Kyiv: Tandem. P. 156. [in Ukrainian].

12 Safin O.D. (1997). Psykholohiia upravlinskoi diialnosti komandyra: Navchalnyi posibnyk [The psychology of managerial activity of the commander: Study Guide]. Khmelnytskyi: Publishing House of the PVU Academy. P. 149 [in Ukrainian].

${ }^{13}$ Leontev A.N. (1971). Potrebnosti, motivy, emotsii [Needs, motives, emotions]. Politizdat. P 79. [in Russian].

14 BodalevA.A. (1993) Psihologija mezhlichnostnyh otnoshenij (k 100-letijuso dnja rozhdenija V.N. Mjasishheva). [Psychology of interpersonal relations (to the 100th anniversary of the birth of V.N. Mjasishheva)]. //Voprosy psihologii. -№2. - 86s. [in Russian] 
the person to the set of material and spiritual public goods, ideals, which are the objects of goals and means for meeting the needs of the vital activity of the individual».

According to S. Rubinstein, it is in human activity to meet immediate public needs that the social scale of values is manifested. At satisfaction of personal and individual needs by means of socially useful activity the attitude of the person to society is realized, and hence the comparison of personal and socially significant.

In this regard, the scientist emphasizes that «... values are not primary. They do not need to begin analysis: they are derived from the juxtaposition of the world and person, they reveal what is in the world, encompassing what creates person in the process of history. Value is the significance of something for a person in the world. Such values are an ideal for her - an idea whose meaning expresses something more meaningful" ${ }^{15}$ (Rubinshtein, 1989).

Psychological content of value orientation was investigated by A. Zdravomyslov by studying her attitude to work. Under the value orientations he understood "the setting of personality on certain values of material and spiritual culture of society.

Value orientations - the most important component of the structure of personality, which in a unique way summarizes the whole life experience, accumulated personality in his individual development. They are a component of personality structure, that is, a certain axis of consciousness, around which the thoughts and feelings of a person revolve, and on which many vital questions are determined." A. Zdravomyslov thought that it is the value orientations as the most important component of the structure of personality that determine his behavior and attitude to the outside world, and therefore this concept is very close to the concepts used in psychology «setting», «need» and «interest» ${ }^{16}$.

In addition, the scientist gave a functional definition of value orientations - «regulation of behavior as a conscious action under certain social conditions.»

The main socio-psychological problem associated with the acquisition and development of knowledge, norms and social models, which are expressed in the value orientations of the individual, is the complementarity of psychoformations in the inner world of the individual. The point is that in the personality, including the personality of the cadet, not all possessed

${ }^{15}$ Rubinshtein S.L. (1989). Osnovy obshchei psikhologii. V 2 t. T. 1 [Fundamentals of General Psychology. In 2 vols. Vol. 1]. Moscow: APN USSR. P 337. [in Russian]

${ }^{16}$ Zdravomyslov A.G. 1964. Potrebnosti. Interesy. Tsennosti. [Needs. Interests Values.]. Leningrad: Publishing House of Leningrad State University. P. 89. [in Russian] 
knowledge and norms become regulators of behavioral activity, and therefore actions can develop in two directions:

a) «I know that there are such norms, but I act on the principle of expediency» - this knowledge is defined, but not filled with personal meaning;

b) «I know that there are such norms and I am acting in accordance with them» - this knowledge becomes important.

Thus, the culture of interpersonal relationships manifests itself at two levels - at the level of competence in relationships and at the level of the relationship culture. Most often, the research uses the concept of «communicative competence», «competence in communication», which in the most general terms «involves the development of an adequate orientation of the person in themselves - their own psychological potential, the potential of a partner, in the situation.» However, the formation of communicative competence is mainly aimed at acquiring the «technique» of communication, the ability to maintain interpersonal contacts and, using optimal behavioral strategies, to achieve their goals in communication.

In the present day, psycho-communication becomes an important feature in which the automatic transfer of utilitarian behavior to what might be sincere communication takes place, and then only contact means remain from communication. In other words, sometimes by «technology», «transactions», «transituational learning» the moral meaning, the awareness of the humanistic side of personal interaction is lost.

According to G. Batishchev, the concept of «deep communication» can also be described as true cultural communication: after all, «oncommunication» is inherent only to deep culture, while «psychocommunication» is a civilization, an extra-moral, technocratic world. From this, we can assume that the culture of relationships in this tradition should be understood as a value that is realized through maximum openness and sincerity in communication, empathy, and identification with a significant other $^{17}$ (Batishchev, 1987).

\section{Theoretical analysis of the essence of culture of interpersonal relations}

At the same time as the perception of existing relationships and understanding (acceptance or non-acceptance) of socially approved rules and

${ }^{17}$ Batishchev G.S. (1987). Dialektika obshcheniia: gnoseologicheskie i mirovozzrencheskie problemy: Sb nauch tr [Dialectics of communication: epistemological and ideological problems: Collection of Scientific Works] // Institut filosofii AN SSSR [Institute of Philosophy, USSR Academy of Sciences]. Ed. by G. S. Batishchev, B.I. Pruzhinin. Moscow. P. 56. [in Russian]. 
norms, their assessment takes place, which, in turn, leads to regulation and self-control of their behavior. Emotion-volitional aspects are based on at least three grounds: first, on the individual-psychological characteristics of the individual, first of all, his temperament; second, the importance of the value of the particular situation of the subject; third, the situational experiences associated with the most important cognitive components that can act as «operators» in relation to the emotional components of individual social settings. However, depending on the peculiarities of the situation (tense, free, provides information, does not provide it) and the characteristics of the subject (rational or emotional type), you can expect different options for the manifestation of emotional and volitional actions of the subject. Therefore, the culture of interpersonal relationships includes a second, emotional-volitional component that assesses interpersonal relationships and social norms, regulates the behavior of the subject. This component is represented by the socio-psychological phenomena of empathy, self-control of behavior and emotional stability ${ }^{18}$ [(Antonova, 2013).

The result of mnemonic and mental operations on the perception and awareness of interpersonal relationships and emotional-volitional regulation of their behavior are changes in the needs-motivational sphere of the individual and his or her value orientations.

The basis of the whole system of human relations with the outside world is the set of his needs and motives.

This sphere of personality determines the selectivity and sets the system of readiness for action against different objects of the surrounding reality.

The necessity-motivational sphere as the primary determines the specificity of the value-orientation sphere of the individual and relates to it as general and special. The result of this correlation is the set of attitudes or dispositions, that is, the internal behavioral readiness, which, one way or another, is fixed in the personal structure.

Considering the orientation of the individual as a dynamic tendency, SL. Rubinstein asserted that every dynamic tendency, expressing the directionality of a person, always involves a more or less conscious connection of the individual with something outside him, the relationship of internal and external. In the possibility of reversibility of this relationship between the importance of purpose and desire, the will is the most specific and peculiar trait of human orientation and the tendencies that create it.

18 Antonova N.O. (2003). Tsinnisni oriientatsii u systemi osobystisnykh rys studentiv vyshchoho pedahohichnoho navchalnoho zakladu: dys... kand. psykhol. nauk [Valuable orientations in the system of personality traits of students of higher pedagogical institution: Psych. Sciences Thesis]. Kyiv: Institute of Psychology of the Academy of Pedagogical Sciences of Ukraine named after G.S. Kostyuk. [in Ukrainian] 
One such trend stands out as a special moment is installation. "The establishment of the individual, according to SL Rubinstein, is a position taken by him that is in relation to the set goals or tasks and is expressed in the electoral mobilization and readiness for activities aimed at their realization ${ }^{19}$ (Rubinshtein, 1989).

A.V. Petrovsky argued that no researcher of the problem of activity can get past the theory of installation. The core of scientific research and the main emphasis in the conceptual understanding of the installation are to indicate the dependent nature of the subject's activity from the existing installation, that is, a person's willingness to perceive the world in a certain way, to act in one direction or another ${ }^{20}$ (Petrovsky, 1989).

Thus, the set of previously entrenched, and thus culturally conditioned attitudes, the disposition to one or another behavior and relationships, which are based on the need-motivational and value formation of the individual and will represent for us the essence of a culture of interpersonal relationships.

In this case, the cultural nature of relationships as a behavioral act is determined, first, by the degree of awareness and experience of interpersonal relationships, their relationship with the internal system of values, and second, by the mechanism of manifestation of the first, internal component through the ability to regulate emotional manifestations, volitional efforts in behavior. This ability, that is, the external manifestation of culturalism is considered through the manifestation of a respectful cadets' attitude to each other and conflict-free in interpersonal contacts.

In psychological science, several approaches to understanding the phenomenon of «culture of interpersonal relations» are developed, which in their essence mean a socially approved set of communicative competences.

In the psychological culture of relationships, he identifies three dependent components:

a) understanding and knowledge of self and other people;

b) adequate self-assessment and evaluation of other people;

c) self-regulation of personal states and properties of self-organization of activity, regulation of relationships with other people. At the same time, the basis of such a culture of relationships between people, according to M.V Savchin, is «knowledge of oneself and other people in all their diversity» ${ }^{21}$ (Savchyn, 1997).

${ }^{19}$ Rubinshtein S.L. (1989). Osnovy obshchei psikhologii. V 2 t. T. 1 [Fundamentals of General Psychology. In 2 vols. Vol. 1]. Moscow: APN USSR. P 337. [in Russian]

${ }^{20}$. Petrovsky A.V. (1998). Voprosy istorii i teorii psikhologii [Issues of history and theory of psychology]. Moscow. [in Russian]

${ }_{21}$ Savchyn M.V. (1997). Psykholohichni osnovy rozvytku vidpovidalnoi povedinky osobystosti: Dys... d-ra psykhol. nauk [Psychological bases of development of responsible 
It is worth noting that the process of understanding, adequate self-esteem and evaluation of other people is more about the psychological competence of the individual, rather than its cultural character in relationships. Relation of the content of the concepts of competence in relations and culture

First, the culture of interpersonal relationships is commonly considered to be part of the personality culture, it consists of three components cognitive (knowledge culture), activity (culture of creative interaction) and emotional-volitional (culture of feelings and communication).

Secondly, it is a qualitative correlation of these three components, which allows us to present in the study the levels of culture of interpersonal relations that are derived from the degree of correlation of these components.

Third, it is important to focus on the implementation of a culture of interpersonal relationships: on the one hand, on productive interference with social activities, and on the other, on self-regulation of affective manifestations and the attainment of emotional comfort.

Psychological culture contains a complex of actively realizing culturalpsychological aspirations and corresponding skills", namely:

a) systematic self-education of cultural aspirations and skills;

b) a fairly high level of ordinary and business communication;

b) appropriate mental self-regulation;

c) creative approach to business;

d) the ability to know and realistically evaluate their personality.

S.B.Koval views the psychological culture of the individual "as a systemic multicomponent formation. In his opinion, it can be revealed from the point of view of the following basic aspects: epistemological, procedural-activity, subjective-personal”22 (Koval, 2011).

Corporate interaction is a form of realization of psychological personality culture and acts as:

system of specific human activities;

set of spiritual values;

the process of self-realization of the creative essence of man

This view of the phenomenon of culture, in our view, allows us to distinguish the parameters of the diagnosis of culture of interpersonal relationships, namely:

personality behavior: Dis ... Dr. psych. Sciences]. Kyiv: Institute of Pedagogy and Psychology of Professional Education of the Academy of Pedagogical Sciences of Ukraine. P. 374. [in Ukrainian].

${ }^{22}$ Koval S.B. (2001). Psykholohichni chynnyky rozvyvalnoi komunikatyvnoi sytuatsii u vyshchykh zakladakh osvity: Dys... kand. psykhol. Nauk [Psychological factors of developmental communicative situation in higher educational establishments: Dis ... Cand. psych. Sciences]. Ivano-Frankivsk: Vasyl Stefanyk Carpathian University. P. 136. [in Ukrainian] 
psychological literacy of interpersonal relationships;

psychological competence in interpersonal relationships;

value-semantic component of interpersonal relations;

the ability to reflect and cultivate in the sphere of interpersonal interaction.

Given that the main form of communication competencies is the process of communication, analysis of communication culture should also be done through a culture of interpersonal relationships. The culture of interpersonal communication is, firstly, a means of communication between people, and secondly, the quality of communication of people at a certain stage of social development. " to analyze the levels of culture of such communication by taking into account the knowledge, the ability to use its means of communication, and also to observe the relevant norms ${ }^{23}$.

The general characteristics of the analyzed culture of interpersonal relationships are certainly realized through special, specific, specific environmental conditions, a social environment characterized by a number of features:

the nature of leading activities determines a special system of relationships, which is based, on the one hand, on the rigid regulation of all life, and, on the other, on the selectivity and variability of creating interpersonal dyads, triads, etc.;

homogeneity and relative age homogeneity of the cadets subdivisions defines and brings in the interpersonal relations of cadets high significance of ideals of youth subculture, which is not always identical with the ideal idea of the defender of the Motherland, criteria of honor, decency in relations, etc .;

Thus, the set of previously entrenched, and therefore, culturally predetermined, attitudes to one or another of the behaviors and attitudes that underlie the need-motivational and value formation of the individual, and can be called the essence of a culture of interpersonal relationships. This component, in its most general form, can be defined as another criterion of this culture, namely, a positive motivational system of relationships to a significant other.

23 Topolnytska H.Iu. (2011). Psykholohichni aspekty bazovykh tsinnostei moralnoi povedinky ofitsera-prykordonnyka [Psychological Aspects of Basic Values of Moral Behavior of Border Guard Officer] // Visnyk Natsionalnoi akademii Derzhavnoi prykordonnoi sluzhby Ukrainy : elektron. nauk. fakh. vyd. / hol. red. Hriaznov I. O [Bulletin of the National Academy of State Border Guard Service of Ukraine: electronic issue. Ed. Hriaznov I.O.]. Vol. 5. URL: http://www.nbuv.gov.ua/e-journals/Vnadps/2011_5/11tgupop.pdf [in Ukrainian]. 
In view of the fact that instructional behavior is only part of a more general psychological trait, in particular the personality orientation, it is necessary to proceed to the analysis of this element of the proposed scheme.

Obviously, orientation is based on a system of needs and motives that are inextricably linked to the value-oriented sphere of the individual. At the same time, it should be emphasized that the concepts of social setting can also trace the direct connection of value orientations with the specific need and conditions of activity in which this need can be satisfied. The change and fixing (fixation) of a social setting is also caused by the appropriate relationship between needs and situations in which they are met. The general scheme here is as follows: orientation - disposition - conditions of activity.

Dispositions are central to the scheme and central to the problematic culture of relations to the significant other. If they are a product of a «clash» of needs and situations in which the corresponding needs can be met and if they are fixed (fixed) in the personal structure, then it is natural to assume that these dispositional entities are formed into a certain system of dispositions, that is, into some culturally entrenched system of relations. The theoretical basis for considering the culture of interpersonal relationships through a system of dispositions is the dispositional concept of personality by V. Yadov ${ }^{24}$ (Yadov, 2000) (Table 1.4).

Table 1.3

The system of dispositions (by Yadov concept)

\begin{tabular}{|c|c|c|c|}
\hline Dispositions & Level of needs & Activity & Level of situations \\
\hline $\begin{array}{c}\text { Culture of } \\
\text { relations }\end{array}$ & Life goals & $\begin{array}{c}\text { System of value } \\
\text { orientations }\end{array}$ & $\begin{array}{c}\text { General social } \\
\text { conditions }\end{array}$ \\
\hline $\begin{array}{c}\text { A series of } \\
\text { actions }\end{array}$ & Personal interests & Basic social settings & Social spheres \\
\hline Act & Social need & $\begin{array}{c}\text { Social fixed } \\
\text { installations }\end{array}$ & Social situation \\
\hline Behavioral act & Greeting needs & $\begin{array}{c}\text { Elementary fixed } \\
\text { installations }\end{array}$ & Subject situation \\
\hline
\end{tabular}

It should be noted that according to developed by V. Yadov dispositional theory of personality, individual settings do not exist in a person by themselves, but are organized in the form of a certain hierarchical system of dispositions. The first (lower) level is elementary installations, which are formed on the basis of vital needs, and therefore are not characterized by modality; the second is the system of social attitudes (cognitive, emotional,

${ }^{24}$ Yadov V.Ya. (2000). Dispozitsionnaia kontseptsiia lichnosti [Dispositional concept of personality] // Sotsialnaia psikhologiia $v$ trudakh otechestvennykh psikhologov [Social psychology in the works of domestic psychologists]. St. Petersburg. 512 p. [in Russian] 
behavioral), occurring in individuals on the basis of specific social objects and situations; the third is basic social settings that determine the general orientation of human activity; the fourth - for the purpose of life and the means of achieving them. The behavioral system of the dispositional hierarchy is structured and reduced to a state of stable integrity, depending on the processes occurring in the cognitive, emotional spheres and in the personality orientation. At the same time, based on the research hypothesis, the cultural nature of relationships as a behavioral act can be determined, first, through the degree of awareness and experience of interpersonal contacts, their relation to the internal value system, and second, by the mechanism of manifestation of the first, internal component, ie ability to regulate emotional reactions, volitional efforts in behavioral acts.

Thus, the culture of interpersonal relationships in cadets is a qualitative and integral characteristic of relationships, since it involves both awareness of relationships as values, and regulation of their emotional-volitional feelings, and adequate behavior within socially significant and professionally valid norms and traditionally valid norms and traditions. and a specific kind of culture.

The external manifestation of the culture of these relationships is the set of behavioral acts that are the form and result of the presence of internal fixed installations that function in the unity of the cognitive and emotionalvolitional components in the general flow of personality orientation. The main criteria for the culture of interpersonal relationships are:

a) representation and understanding of established relationships;

b) emotional-volitional stability of relationships;

c) a positive motivational system towards others.

\section{CONCLUSION}

Summarizing the results of different approaches to the culture of interpersonal relationships, it is appropriate to highlight and note the general that combines approaches with each other and that is the basis for further consideration of the studied phenomenon of culture of interpersonal relationships. These summaries can be summarized in the following main points.

Communicative competence is a psychological phenomenon that has traits that can be recorded externally and that manifest themselves primarily in behavioral acts, as well as internal causes that lead to such behavior. Speaking of outward signs, it is a continuity of socially approved behavioral acts (instructive behavior) that are positively perceived by the vast majority of members of society. It is about the norms of politeness, respectful treatment of others, and the etiquette of relationships that are generally accepted in society. These external manifestations are generally evaluated in 
two dimensions - the dimension of the social, which defines the common component of the culture of interpersonal relationships, and the dimension of the stratometric, corporate, which, in addition to the general component, also covers some specific behavioral characteristics that a certain community (in our case, is a community ) will also be considered a cultural communicati Rubinshtein S.L. (1989 ve competence).

\section{REFERENCES}

1. Antonova N.O. (2003). Tsinnisni oriientatsii u systemi osobystisnykh rys studentiv vyshchoho pedahohichnoho navchalnoho zakladu: dys... kand. psykhol. nauk [Valuable orientations in the system of personality traits of students of higher pedagogical institution: Psych. Sciences Thesis]. Kyiv: Institute of Psychology of the Academy of Pedagogical Sciences of Ukraine named after G.S. Kostyuk. [in Ukrainian]

2. Bodalev A.A. (1993). Psihologija mezhlichnostnyh otnoshenij (k 100letijuso dnja rozhdenija V.N. Mjasishheva). [Psychology of interpersonal relations (to the 100th anniversary of the birth of V.N. Mjasishheva)]. //Voprosy psihologii. -№2. - 86s. [in Russian]

3. Buzin E. V. (1992). Mezhlichnostnoe ponimanie kak faktor effektivnosti uchebno-professionalnoi deiatelnosti gruppy kursantov Avtoref dis kand psikhol nauk [Interpersonal understanding as a factor in the effectiveness of educational and professional activities of a group of cadets: Author's abstract. diss. psych. sciences]. Kyiv. P.22 [in Russian]

4. Batishchev G.S. (1987). Dialektika obshcheniia: gnoseologicheskie $i$ mirovozzrencheskie problemy: Sb nauch tr [Dialectics of communication: epistemological and ideological problems: Collection of Scientific Works] // Institut filosofii AN SSSR [Institute of Philosophy, USSR Academy of Sciences]. Ed. by G. S. Batishchev, B.I. Pruzhinin. Moscow. P. 56. [in Russian]

5. Zazhyrko M.P. (1998). Hlybynnopsykholohichni peredumovy aktyvizatsii protsesu spilkuvannia (akmeolohichnyi pidkhid): Dys... kand. psykhol. Nauk [Deep-psychological preconditions for activating the communication process (acmeological approach): Dis ... Cand. Psych. Sciences]. Cherkasy: Cherkasy State University named after B. Khmelnytskyi. P. 47. [in Ukrainian]

6. Zdravomyslov A.G. 1964. Potrebnosti. Interesy. Tsennosti. [Needs. Interests Values.]. Leningrad: Publishing House of Leningrad State University. P. 89. [in Russian]

7. Koval S.B. (2001). Psykholohichni chynnyky rozvyvalnoi komunikatyvnoi sytuatsii u vyshchykh zakladakh osvity: Dys... kand. psykhol. Nauk [Psychological factors of developmental communicative situation in 
higher educational establishments: Dis ... Cand. psych. Sciences]. IvanoFrankivsk: Vasyl Stefanyk Carpathian University. P. 136. [in Ukrainian]

8. Leontev A.N. (1971). Potrebnosti, motivy, emotsii [Needs, motives, emotions]. Politizdat. P 79. [in Russian]

9. Miasishchev V.N. (1995). Psikhologiia otnoshenii [Psychology of relations]. Moscow. 229 p. [in Russian]

10. Naprasna O.B. (2004). Indyvidualno-psykholohichni osoblyvosti kohnityvno-stylovykh kharakterystyk navchalnoi diialnosti studentiv: Dys... kand. psykhol. nauk [Individual-psychological features of cognitive-style characteristics of students' educational activity: Dis ... Cand. psych. sciences]. Kyiv: The Taras Shevchenko National University of Kyiv. P. 188. [in Ukrainian]

11. Petrovsky A.V. (1998). Voprosy istorii i teorii psikhologii [Issues of history and theory of psychology]. Moscow. [in Russian]

12. Rubinshtein S.L. (1989). Osnovy obshchei psikhologii. V 2 t. T. 1 [Fundamentals of General Psychology. In 2 vols. Vol. 1]. Moscow: APN USSR. P 337. [in Russian]

13. Safin O.D. (1997). Psykholohiia upravlinskoi diialnosti komandyra: Navchalnyi posibnyk [The psychology of managerial activity of the commander: Study Guide]. Khmelnytskyi: Publishing House of the PVU Academy. P. 149 [in Ukrainian]

14. Savchyn M.V. (1997). Psykholohichni osnovy rozvytku vidpovidalnoi povedinky osobystosti: Dys... d-ra psykhol. nauk [Psychological bases of development of responsible personality behavior: Dis ... Dr. psych. Sciences]. Kyiv: Institute of Pedagogy and Psychology of Professional Education of the Academy of Pedagogical Sciences of Ukraine. P. 374. [in Ukrainian]

15. Topolnytska H. Yu. (2006). Zmina sotsialnykh ustanovok i vplyv kolektyvno-psykholohichnykh umov na formuvannia kultury mizhosobystisnykh vidnosyn $\mathrm{v}$ kursantskykh kolektyvakh [Changing social attitudes and the influence of collective-psychological conditions on the formation of a culture of interpersonal relations in cadets] // Zbirnyk naukovykh prats № 35. Chast. II [Collection of scientific works No. 35. Part. II]. Khmelnytskyi: Vyd-vo Natsionalnoi akademii DPSU [Published by the National Academy of the SBGS of Ukraine]. P. 134. [in Ukrainian]

16. Topolnytska H.Iu. (2011). Psykholohichni aspekty bazovykh tsinnostei moralnoi povedinky ofitsera-prykordonnyka [Psychological Aspects of Basic Values of Moral Behavior of Border Guard Officer] // Visnyk Natsionalnoi akademii Derzhavnoi prykordonnoi sluzhby Ukrainy : elektron. nauk. fakh. vyd. / hol. red. Hriaznov I. $O$ [Bulletin of the National Academy of State Border Guard Service of Ukraine: electronic issue. Ed. 
Hriaznov I.O.]. Vol. 5. URL: http://www.nbuv.gov.ua/e-journals/ Vnadps/2011_5/11tgupop.pdf_[in Ukrainian]

17. Yahupov V.V. (2000). Upravlinski funktsii ofitsera ta yikh pedahohichnyi zmist [The managerial functions of the officer and their pedagogical content] // Visnyk AU pry Prezydenti Ukrainy [Bulletin of the AU under the President of Ukraine]. Vyd-vo UADU. Vol. 2. P. 307. [in Ukrainian]

18. Yahupov V.V. (2004). Viiskova psykholohiia: Pidruchnyk [Military Psychology: Textbook]. Kyiv: Tandem. P. 156. [in Ukrainian]

19. Yadov V.Ya. (2000). Dispozitsionnaia kontseptsiia lichnosti [Dispositional concept of personality] // Sotsialnaia psikhologiia v trudakh otechestvennykh psikhologov [Social psychology in the works of domestic psychologists]. St. Petersburg. 512 p. [in Russian]

\section{Information about the author: \\ Halyna Topolnytska,}

Candidate of Psychological Sciences, Associate Professor,

Associate Professor in the Department of Psychology,

Moral and Psychological Support

The Bohdan Khmelnytskyi National Academy

of State Border Guard Service of Ukraine

46, Shevchenko St., Khmelnytskyi, Ukraine, 29003

ORCIDID: orcid.org/0000-0001-8316-0859

topgalina@i.ua 